\title{
Evaluation of Animal Rabies Surveillance System, Ekiti State, Nigeria, 2012-2017
}

\author{
Joyce O. Adebayo1, 2, Victor A. Ojo², Gabriel Ogundipe ${ }^{3}$, Patrick M. Nguku \\ ${ }^{1}$ Nigeria Field Epidemiology and Laboratory Training Program (NFELTP), Abuja, Nigeria, ${ }^{2}$ Ministry of Agriculture and Rural Development, Ado Ekiti, \\ Ekiti State, Nigeria, ${ }^{3}$ University of Ibadan, Ibadan, Oyo State, Nigeria
}

\section{Objective}

The objectives of this study are to evaluate the current animal rabies surveillance system in the state and suggest recommendations.

Introduction

Rabies is a zoonotic, neglected viral disease. Every 10 minutes, the world loses a life, especially children, to dog-mediated rabies. Yet it is $100 \%$ preventable. Africa, including Nigeria, has major share of the disease. Eradication of human rabies relies majorly on control of rabies in animals and this cannot be achieved without good surveillance system of the disease in animal, especi ally dogs. There is little or no information as to whether the surveillance system in Nigeria is effective.

\section{Methods}

We reviewed the medical records of all rabies cases reported in the 10 government and 5 registered private veterinary health facilities in the 16 LGAs of the state. We extracted 44 cases of rabies in all, between review period of 2012-2017. We also interviewed 25 key stakeholders in the system using Key Informant Interview (KII) and questionnaires. We followed the steps stated in CDC guideline for evaluation of public health surveillance system to assess the key attributes and components of the system, and analysed the data using Microsoft Excel.

\section{Results}

Two (20\%) of the government and only one in five private veterinary health facilities had records on rabies cases. All reported cases of suspected rabies involved dog bites. The confirmatory status of $32(72.7 \%)$ of the suspected cases were unknown. Six (37.5\%) LGAs did not have access to any veterinary health facility. Average of 1 technical staff per veterinary facility was seen. Overall, the system was useful and flexible. It was fairly simple, acceptable and representative. Both sensitivity and predictive Value Positive (PVP) were less than $1 \%$ while the timeliness, data quality and stability were poor.

\section{Conclusions}

The surveillance system was performing below optimal level. There is need for improvement in the animal rabies surveillance system to achieve elimination of human rabies in Nigeria.

\section{Acknowledgement}

1. Nigeria Field Epidemiology and Laboratory Training Program, Abuja, Nigeria

2. Ministry of Agriculture and Rural Development, Ado-Ekiti, Ekiti State, Nigeria

\section{References}

Adedeji AO, Okonko IO, Eyarefe OD, Adedeji OB, Babalola ET, et al. 2010. An overview of rabies - History, epidemiology, control and possible elimination. Afr J Microbiol Res. 4(22), 2327-38.

Aliyu T. 2010. Prevalence of Rabies Virus Antigens in Apparently Healthy Dogs in Yola, Nigeria. Researcher. 2(2), $1-14$. 
Ameh VO, Dzikwi AA, Umoh JU. 2014. Assessment of Knowledge, Attitude and Practice of Dog Owners to Canine Rabies in Wukari Metropolis, Taraba State Nigeria. Glob J Health Sci. 6(5), 226-40. PubMed

Burgos-Cáceres, S. 2011. Canine Rabies: A Looming Threat to Public Health. Animals (Basel). 1(4), 326-42. PubMed

Dutta JK, Dutta TK. 1994. Rabies in endemic countries. BMJ. 308(6927), 488-89. PubMed

Ehimiyein AM, Ehimiyein IO. 2014. Rabies- Its Previous and Current Trend as an Endemic Disease of Humans and Mammals in Nigeria. J Exp Biol Agric Sci. 2(2320), 137-49.

El-moamly A. 2014. Immunochromatographic Techniques: Benefits for the Diagnosis of Parasitic Infections. Austin Chromatography, 1(4), 1-8. Fekadu, M. (1993). Canine rabies. J Vet Res (Pulawy). 60, 421-27.

Kasempimolporn S, Saengseesom W, Huadsakul S, Boonchang S, Sitprija V. 2011. Evaluation of a rapid immunochromatographic test strip for detection of Rabies virus in dog saliva samples. J Vet Diagn Invest. 23(6), 1197-201. PubMed

Muriuki J, Thaiyah A, Mbugua S, Kitaa J, Kirui G. 2016. Knowledge, Attitude and Practices on Rabies and Socioeconomic Value of Dog Keeping in isumu and Siaya countries, Kenya. Int J Vet Sci. 5(1), 29-33.

National Population Commission. 2009. 2006 population and housing census of the Federal Republic of Nigeria. Official Gazette of the Federal Republic of Nigeria. 96(2), 1.

Ogunkoya A, Aina O, Adebayo O, Oluwagbenga A, Tirmidhi A, et al. 2012. Rabies Antigen Spread Amongst Apparently Healthy Dogs in Nigeria: A Review. Rita Brazil. 8(October), 74.

OIE. World Organization for Animal Health. (2012). OIE Global Conference on Rabies Control: OIE - World Organisation for Animal Health. on-rabies-control

OIE: World Organization for Animal Health. (2014). Dog vaccination: the key to end dog-transmitted human rabies: OIE - World Organisation for Animal Health.

Otolorin GR, Umoh JU, Dzikwi AA, Anglais AE. 2014. Prevalence of Rabies Antigen in Brain Tissue of Dogs Slaughtered for Human Consumption and Evaluation of Vaccination of Dogs Against Rabies in Aba, Abia State Nigeria. World J Public Health Sciences. 3(1), 5-10.

Panda S, Mitra J, Chowdhury S, Sarkar SN. 2016. Detection Of Rabies Viral Antigen In Cattle By Rapid Immunochromtographic Diagnostic Test. Explor Anim Med Res. 6(1), 119-22.

Sharma P, Singh CK, Narang D. 2015. Comparison of immunochromatographic diagnostic test with heminested r everse transcriptase polymerase chain reaction for detection of rabies virus from brain samples of various species. Vet World. 8(2), 135-38. PubMed

Singh CK, Kaw A, Bansal K, Dandale M, Pranoti S. 2012. Approaches for antemortem diagnosis of rabies 1. CIBTech Journal of Biotechnology. 1(1), 1-16.

Takayama N. 2008. Rabies: A preventable but incurable disease. J Infect Chemother. 14(1), 8-14. PubMed

Wang H, Feng N, Yang S, Wang C, Wang T, et al. 2010. A rapid immunochromatographic test strip for detecting rabies virus antibody. $J$ Virol Methods. 170(1-2), 80-85. PubMed

WHO. (2016). WHO | Rabies. WHO.

Wu X, Hu R, Zhang Y, Dong G, Rupprecht CE. 2009. Reemerging rabies and lack of systemic surveillance in People's Republic of China. Emerg Infect Dis. 15(8), 1159-64. PubMed

ISDS Annual Conference Proceedings 2019. This is an Open Access article distributed under the terms of the Creative Commons AttributionNoncommercial 4.0 Unported License (http://creativecommons.org/licenses/by-nc/3.0/), permitting all non-commercial use, distribution, and reproduction in any medium, provided the original work is properly cited. 